\title{
Feeding rolled barley grain steeped in lactic acid modulated energy status and innate immunity in dairy cows
}

\author{
S. Iqbal, Q. Zebeli, A. Mazzolari, ${ }^{1}$ S. M. Dunn, and B. N. Ametaj ${ }^{2}$ \\ Department of Agricultural, Food and Nutritional Science, University of Alberta, Edmonton, AB, Canada T6G 2P5
}

\section{ABSTRACT}

Feeding dairy cows large proportions of cereal grain is commonly associated with rumen acidosis, activation of innate immunity, and perturbation of intermediary metabolism. We previously showed that steeping barley grain in $0.5 \%$ lactic acid (LA) decreased the rate of starch degradation, lowered the risk of subacute rumen acidosis, modulated rumen fermentation profile, and increased milk fat content in dairy cows. This study sought to investigate whether feeding of LA-treated barley grain would affect carbohydrate and lipid metabolism as well as innate immunity. Eight rumen-fistulated latelactation (approximately $217 \mathrm{~d}$ in milk, DIM) Holstein cows were randomly assigned, in a $2 \times 2$ crossover design, to 1 of the 2 dietary treatments consisting of $27 \%$ (dry matter basis) rolled barley grain steeped for $48 \mathrm{~h}$ in an equal volume (wt/vol) of tap water (CTR) or $0.5 \%$ LA (TRT). Each experimental period lasted $21 \mathrm{~d}$, with the first $11 \mathrm{~d}$ for diet adaptation. Blood and rumen samples were collected on d 12, 15, 17, and 21 of the experimental period before the morning feeding to evaluate the effects of dietary treatment on preprandial day-to-day variation of plasma and rumen variables. To establish the effect of treatment on diurnal variation of plasma variables, blood samples were collected on the last day of each period at $0,2,4,6,8,10$, and 12 $\mathrm{h}$ after the morning feeding (i.e., $0800 \mathrm{~h}$ ). Results of the day-to-day study showed that cows fed the TRT diet had greater overall preprandial concentrations of glucose, cholesterol, and insulin, and a lower concentration of haptoglobin in plasma. Diurnal data indicated lower concentrations of haptoglobin and serum amyloid $\mathrm{A}$ and a tendency for greater plasma lactate in cows fed the TRT diet. A treatment by time interaction was observed for glucose, lactate, insulin, haptoglobin, and lipopolysaccharide-binding protein, suggesting a role for both the processing of grain and the time of sampling on

Received January 29, 2010.

Accepted August 12, 2010.

${ }^{1}$ Current address: Pioneer Hi-Bred Italia, Via Pari Opportunita 2, 26030 Gadesco Pieve Delmona, Cremona, Italy.

${ }^{2}$ Corresponding author: burim.ametaj@ualberta.ca those variables. No effect of diet on plasma concentrations of cortisol, $\beta$-hydroxybutyrate, and nonesterified fatty acids or rumen endotoxin was evidenced. Taken together, our results demonstrated that feeding barley grain steeped in $0.5 \%$ LA modulated both energy status and innate immunity of dairy cows fed relatively high levels ( $45 \%$ of dry matter) of dietary concentrate.

Key words: barley grain, lactic acid, metabolic response, acute phase protein

\section{INTRODUCTION}

Although dietary formulations are known to play a pivotal role in preventing metabolic disorders in dairy cows, it is often difficult to formulate a well-balanced diet, particularly in terms of balancing rumen degradable carbohydrates and dietary fiber (Zebeli et al., 2010). Diets for this group of cattle are designed to contain high proportions of cereal grains rich in readily available carbohydrates to support the production of high amounts of milk. However, feeding dairy cows diets rich in starch is associated with the rapid release of large amounts of short-chain fatty acids that have been implicated in the development of acute and subacute rumen acidosis (SARA; Nocek, 1997) and other related diseases (Andersen, 2003; Ametaj et al., 2005). High grain-low forage diets also have been reported to be associated with initiation of an innate immune response as a reaction to absorption of rumen free endotoxin (ET) into the blood circulation (Emmanuel et al., 2007, 2008). Therefore, most efforts of the scientific community have been directed at processing cereal grains to maximize grain efficiency and enhance its health benefits.

Over the years, different physical processing technologies such as grinding, rolling, cracking, or steaming and chemical treatments such as sodium hydroxide, ammonia, formaldehyde, or ammonium hydroxide have been used to prevent health implications (e.g., SARA, laminitis, and displaced abomasum) and improve feed efficiency of cereal grains in cattle (Theurer, 1986; Campling, 1991). Most of the physical processing technologies have been embraced by the dairy industry and have increased the efficiency of cereal grain use in cattle 
(Theurer, 1986; Campling 1991); however, chemical processing has not been very successful. Some of the chemical compounds tested are expensive, others are corrosive in nature and pose health risks to laborers, or they do not meet the expected health and productive benefits of the producers. The dairy industry has been reluctant to use most of the chemical processing technologies developed over the last 2 decades.

Lactic acid (LA) is a mild organic acid produced by lactic acid bacteria, and it is widely used as a lowcost means of food preservation by different industries. Interestingly, previously published data from our team (Iqbal et al., 2009) demonstrated that feeding dairy cows barley grain steeped in $0.5 \%$ LA for $48 \mathrm{~h}$ had several beneficial effects including (1) slowing barley grain degradation rate in the rumen within the first $24 \mathrm{~h}$, (2) lowering concentrations of VFA and lactate in the rumen fluid, (3) maintaining rumen $\mathrm{pH}$ above SARA levels (i.e., >5.8) during the most intensive fermentation hours (6 to $12 \mathrm{~h}$ after feeding), (4) increasing the amount of resistant starch and decreasing the amount of soluble starch in the barley grain, and (5) enhancing milk fat content (Iqbal et al., 2009). Because of the aforementioned beneficial effects of barley grain treated with LA, we extended our hypothesis to evaluate whether steeping rolled barley grain in LA would affect energy status and innate immunity of dairy cows.

Therefore, the objectives of the present investigation were to (1) evaluate the effects of feeding rolled barley grain steeped in LA on diurnal and day-to-day preprandial responses of selected plasma metabolites related to carbohydrate and lipid metabolism, and (2) determine whether feeding of LA-treated barley grain would modulate innate immunity of late-lactation dairy cows as reflected by plasma concentration of serum amyloid A (SAA), lipopolysaccharide-binding protein (LBP), and haptoglobin $(\mathbf{H p})$.

\section{MATERIALS AND METHODS}

\section{Cows, Diets, and Experimental Design}

Eight ruminally cannulated (100 mm i.d. cannula, Bar Diamond, Parma, ID) primiparous Holstein cows were used in this experiment. Upon commencement of the experiment, the cows were at 198 to 236 DIM, had an average milk production of $28 \mathrm{~kg} / \mathrm{d}$, and weighed $680 \pm 30 \mathrm{~kg}$. The cows were assigned to 1 of 2 dietary treatments according to a paired $2 \times 2$ crossover design with 2 study periods. Each experimental period was $21 \mathrm{~d}$, with the first $11 \mathrm{~d}$ used for adaptation to diets and the last $10 \mathrm{~d}$ for experimental measurements. Cows were offered a TMR containing, on a DM basis, $15 \%$ alfalfa hay, $40 \%$ barley silage, and $18 \%$ energy and protein supplement (Table 1). In addition, 27\% (DM basis) rolled barley grain, steeped in an equal quantity (i.e., in a 1:1 ratio, wt/vol) of tap water alone (CTR) or $0.5 \%$ LA solution (TRT), was added to the TMR just before the morning feeding. Dry matter content of untreated rolled barley grain was $85.4 \pm 1.25 \%$ and decreased to $42.7 \pm 1.13 \%$ and $43.1 \pm 1.32 \%$ (mean $\pm \mathrm{SD}$ ) after steeping it in tap water or $0.5 \%$ LA, respectively. Rolled barley was steeped for $48 \mathrm{~h}$ before being mixed with the TMR. The LA (DL-lactate, $85 \%$, wt/wt) used in this study was purchased from Sigma (Oakville, Ontario, Canada).

During the 11-d collection periods, the weight of feed offered and refused was recorded daily. Feed ingredient samples were collected twice weekly. Diet ingredients were dried in a $55^{\circ} \mathrm{C}$ forced-air oven for $72 \mathrm{~h}$ to prepare the samples for grinding. The dried samples were ground through a 1-mm screen using a Wiley mill (ThomasWiley, Philadelphia, PA). Samples were analyzed for concentrations of DM, ash, NDF, ADF, CP, and starch. The DM content was determined by drying samples at $135^{\circ} \mathrm{C}$ for $2 \mathrm{~h}$ (AOAC, 2002; method 930.15). Ether extract was determined using a Goldfisch extraction apparatus (Labconco, Kansas City, MO; Rhee, 2005). Ash concentration was determined after $5 \mathrm{~h}$ at $550^{\circ} \mathrm{C}$ in a furnace (AOAC, 2002; method 942.05). Methods of Van Soest et al. (1991) were used in the analyses of NDF and ADF using heat-stable amylase and sodium sulfite in the case of NDF. Crude protein was quantified by flash combustion with gas chromatography and thermal conductivity detection (Carlo Erba Instruments, Milan, Italy).

The contents of $\mathrm{CP}, \mathrm{NDF}$, starch, and $\mathrm{NE}_{\mathrm{L}}$ were similar across different diets. Ingredients and chemical composition of the diets are presented in Table 1 . The diets were formulated to meet or exceed the requirements of a $680-\mathrm{kg}$ lactating cow producing about $25 \mathrm{~kg}$ of milk/d with $3.5 \%$ fat as per NRC (2001) guidelines. The cows were fed for ad libitum intake to allow at least $5 \%$ orts. The cows were housed in individual tie stalls bedded with sawdust, and had free access to water. Diets were fed once daily at $0800 \mathrm{~h}$. The orts were collected daily at $0700 \mathrm{~h}$ from each individual cow. Feed intake was calculated as a difference between the amounts of feed offered and weighed back on the next morning.

All experimental procedures were approved by the University of Alberta Animal Care and Use Committee for Livestock, and animals were cared for in accordance with the guidelines of the Canadian Council on Animal Care (1993). Veterinary supervision was provided to the animals throughout the experiment.

\section{Sample Collection}

Blood samples were collected from the coccygeal vessels on d 12,15, 17, and 21 of the experimental periods 
Table 1. Ingredients and chemical composition of the experimental diets

\begin{tabular}{|c|c|c|}
\hline \multirow[b]{2}{*}{ Item } & \multicolumn{2}{|c|}{$\operatorname{Diet}^{1}$} \\
\hline & CTR & TRT \\
\hline \multicolumn{3}{|l|}{ Ingredient, $\%$ of DM } \\
\hline Alfalfa hay & 15.0 & 15.0 \\
\hline Barley silage & 40.0 & 40.0 \\
\hline Rolled barley grain (water-treated) & 27.0 & - \\
\hline Rolled barley grain (LA-treated) & - & 27.0 \\
\hline Ground barley grain & 4.96 & 4.96 \\
\hline Canola meal & 1.21 & 1.21 \\
\hline Corn gluten meal & 7.81 & 7.81 \\
\hline Canola oil & 0.45 & 0.45 \\
\hline Biofos $^{2}$ & 0.22 & 0.22 \\
\hline Dairy premix ${ }^{3}$ & 0.76 & 0.76 \\
\hline Limestone & 0.90 & 0.90 \\
\hline Sodium bicarbonate & 0.67 & 0.67 \\
\hline Molasses & 0.63 & 0.63 \\
\hline Magnesium oxide & 0.18 & 0.18 \\
\hline Vitamin E $(5,000 \mathrm{IU} / \mathrm{kg})$ & 0.03 & 0.03 \\
\hline Vitamin $\mathrm{D}_{3}(500,000 \mathrm{IU} / \mathrm{kg})$ & 0.18 & 0.18 \\
\hline \multicolumn{3}{|c|}{ Nutrient composition, $\%$ of DM unless stated } \\
\hline DM & 57.8 & 57.8 \\
\hline Ash & 8.12 & 8.09 \\
\hline $\mathrm{CP}$ & 16.6 & 16.5 \\
\hline NDF & 35.6 & 35.8 \\
\hline Forage NDF & 30.7 & 30.7 \\
\hline $\mathrm{ADF}$ & 19.3 & 19.4 \\
\hline Starch $^{4}$ & 31.1 & 32.4 \\
\hline Ether extract & 3.28 & 3.31 \\
\hline $\mathrm{NFC}^{5}$ & 36.4 & 36.3 \\
\hline $\mathrm{NE}_{\mathrm{L}},{ }^{6} \mathrm{Mcal} / \mathrm{kg}$ of $\mathrm{DM}$ & 1.58 & 1.58 \\
\hline \multicolumn{3}{|c|}{$\begin{array}{l}{ }^{1} \mathrm{CTR}=\text { control diet containing rolled barley grain steeped for } 48 \mathrm{~h} \text { in equal quantity of tap water; TRT }= \\
\text { treatment diet based on rolled barley grain steeped for } 48 \mathrm{~h} \text { in equal quantity of tap water containing } 0.5 \% \\
\text { lactic acid (LA; vol/vol). }\end{array}$} \\
\hline \multicolumn{3}{|c|}{$\begin{array}{l}{ }^{2} \text { Contained monocalcium phosphate and dicalcium phosphate in the ratio 2:1 (Champion Feed Services Ltd., } \\
\text { Barrhead, Alberta, Canada). }\end{array}$} \\
\hline \multicolumn{3}{|c|}{$\begin{array}{l}{ }^{3} \text { Contained calcium } 0.1 \% \text {, phosphorous } 0.6 \% \text {, sodium } 11.5 \% \text {, magnesium } 0.3 \% \text {, potassium } 0.7 \% \text {, sulfur } 0.23 \% \text {, } \\
\text { zinc } 5,000 \mathrm{mg} / \mathrm{kg} \text {, copper } 1,170 \mathrm{mg} / \mathrm{kg} \text {, manganese } 3,100 \mathrm{mg} / \mathrm{kg} \text {, iodine } 80 \mathrm{mg} / \mathrm{kg} \text {, cobalt } 6.2 \mathrm{mg} / \mathrm{kg} \text {, vitamin } \\
\text { A } 1,265,000 \mathrm{IU} / \mathrm{kg} \text {, vitamin D } 142,000 \mathrm{IU} / \mathrm{kg} \text {, vitamin E } 3,800 \mathrm{IU} / \mathrm{kg} \text {. }\end{array}$} \\
\hline \multicolumn{3}{|c|}{$\begin{array}{l}{ }^{4} \text { The contents of soluble starch and resistant starch (McCleary and Monaghan, 2002) were (DM basis) } 16.4 \% \\
\text { and } 37.8 \%, 19.9 \% \text { and } 46.8 \%, 8.4 \% \text { and } 64.5 \% \text { for original rolled barley grain, CTR-, and TRT-barley grains, } \\
\text { respectively. }\end{array}$} \\
\hline${ }^{5} \mathrm{NFC}=100-(\% \mathrm{NDF}+\% \mathrm{CP}+$ & & \\
\hline
\end{tabular}

at $0800 \mathrm{~h}$, and for diurnal responses only on $\mathrm{d} 21$ of the experimental period every $2 \mathrm{~h}$ starting from 0800 until 2000 h using 10-mL Vacutainer tubes (Becton Dickinson, Franklin Lakes, NJ) containing sodium heparin as an anticoagulant. Blood samples were stored in ice and centrifuged (Rotanta 460 R, Hettich Zentrifugan, Tuttlingen, Germany) within $20 \mathrm{~min}$ at $3,000 \times g$ and $4^{\circ} \mathrm{C}$ for $20 \mathrm{~min}$ to separate plasma. Plasma samples were stored at $-20^{\circ} \mathrm{C}$ until analysis.

To evaluate the effects of treatment on rumen ET, about $250 \mathrm{~mL}$ of the rumen fluid was collected on $\mathrm{d}$ $12,15,17$, and 21 of the experimental period at 0800 h. Rumen fluid samples were collected in the ventral rumen sac through the cannula using a tube fitted with a strainer and syringe into a $140-\mathrm{mL}$ plastic container.
Samples of rumen fluid were centrifuged at $6,000 \times g$ for $15 \mathrm{~min}$ in $4^{\circ} \mathrm{C}$ (Rotanta $460 \mathrm{R}$, Hettich Zentrifugan) and stored at $-20^{\circ} \mathrm{C}$ until the ET analysis was performed.

\section{Sample Analysis}

Quantitative determination of plasma NEFA was done by an enzymatic colorimetric method using commercially available kits (Wako Chemicals, Richmond, VA). Samples were tested in duplicate and the optical density was measured at $550 \mathrm{~nm}$ on a microplate spectrophotometer (Spectramax 190, Molecular Devices Corp., Sunnyvale, CA). The lower detection limit of the assay was $0.50 \mu \mathrm{Eq} / \mathrm{L}$. 
Plasma insulin was measured by commercially available bovine ELISA kit supplied by Mercodia AB (Uppsala, Sweden). This procedure involved a solid-phase, 2 -site enzyme immunoassay. The assay is based on the direct sandwich technique in which 2 monoclonal antibodies are directed against separate antigenic determinants on the insulin molecule. During incubation, insulin in the sample reacts with peroxidase-conjugated anti-insulin antibodies and anti-insulin antibodies bound to the micro titration wells. After simple washing, that removes unbound enzyme labeled antibody, the bound conjugate was detected by reaction with $3,3^{\prime}-5,5^{\prime}$-tetramethylbenzidine. The reaction was stopped by the addition of stop solution giving colorimetric endpoint that can be read spectrophotometrically (Spectramax 190, Molecular Devices Corp.) at $450 \mathrm{~nm}$. The intraassay CV were $<2.74 \%$ for all samples tested.

Enzymaticquantitation ofBHBA by $\beta$-hydroxybutyrate dehydrogenase was used for quantifying plasma concentration of BHBA using a commercially available kit (Stanbio Laboratory, Boerne, TX). Plasma BHBA was measured in duplicate by reading on a microplate spectrophotometer (Spectramax 190, Molecular Devices Corp.) at an optical density of $505 \mathrm{~nm}$. The lower detection limit of the assay was $0.125 \mu \mathrm{mol} / \mathrm{L}$.

Plasma cholesterol was measured using commercially available kits (Diagnostic Chemicals Ltd., Charlottetown, PEI, Canada). All samples were tested in duplicate and plasma cholesterol was determined by reading the optical density values on a microplate spectrophotometer (Spectramax 190, Molecular Devices Corp.) at $505 \mathrm{~nm}$.

Commercially available kits from Biomedical Research Service Center (Buffalo, NY) were used to measure concentration of lactate in plasma. All samples were tested in duplicate and lactate concentration was determined by reading the optical density values on a microplate spectrophotometer (Spectramax 190, Molecular Devices Corp.) at $492 \mathrm{~nm}$.

Plasma cortisol was measured by commercially available enzyme immunoassay kit (Diagnostic Systems Laboratories Inc., Webster, TX). The basic principle of the procedure involves competition between an unlabeled antigen and an enzyme-labeled antigen for a fixed number of antibody binding sites. The amount of enzyme-labeled antibody is inversely proportional to the concentration of the unlabeled analyte present in the solution. Unbound materials were removed by decanting and washing the wells. All samples were in duplicate. The optical density was measured at 450 $\mathrm{nm}$ in a microplate reader (Spectramax 190, Molecular Devices Corp.), and concentration was calculated by using a 4-parameter curve fit. The intraassay CV were $<4.71 \%$ for all the samples tested.
Concentration of cell-free ET in the rumen fluid was determined by the pyrochrome Limulus amebocyte lysate assay (Associates of Cape Cod Inc., East Falmouth, MA), as described by Emmanuel et al. (2008). Briefly, $1.5 \mathrm{~mL}$ of the rumen fluid supernatant was centrifuged at $10,000 \times g$ for $30 \mathrm{~min}$. The supernatant was then passed through a disposable $0.22-\mu \mathrm{m}$ sterile, pyrogen-free filter (Fisher Scientific, Fairlawn, NJ) and diluted 1,000-fold using pyrogen-free Limulus amebocyte lysate reagent water and pyrogen-free test tubes (Associates of Cape Cod Inc.). Samples were tested in duplicate, and the optical density values were read on a microplate spectrophotometer (Spectramax 190, Molecular Devices Corp.) at a wavelength of $405 \mathrm{~nm}$. Intraassay CV were $<3.94 \%$ for all assays.

Concentrations of SAA and $\mathrm{Hp}$ in the plasma were determined by using commercially available bovine ELISA kits (Tridelta Development Ltd., Greystones, Co. Wicklow, Ireland) using the methods of Emmanuel et al. (2008). Briefly, plasma samples were initially diluted 1:500, and samples with optical density values above the range of the standard curve were diluted further (1:400 or 1:250) and reanalyzed. All samples were tested in duplicate, and the optical density values were read on a microplate spectrophotometer (Spectramax 190, Molecular Devices Corp.) at 450 and $630 \mathrm{~nm}$ for SAA and Hp, respectively.

Concentration of LBP in plasma was determined with a commercially available multispecies ELISA kit (Cell Sciences Inc., Norwood, MA) using the method of Emmanuel et al. (2008). Briefly, plasma samples were initially diluted 1:1,000, and samples with optical density values lower than the range of the standard curve were tested with a lower dilution (1:500). Samples were tested in duplicate, and the optical density at 450 $\mathrm{nm}$ was measured on a microplate spectrophotometer (Spectramax 190, Molecular Devices Corp.).

\section{Statistical Analyses}

All data were analyzed using the MIXED procedure (version 9.1.3, SAS Institute, 2003) according to the following model:

$$
\begin{aligned}
Y_{i j k l m n} & =\mu+S_{i}+C(S)_{j(i)}+P_{k}+T_{l} \\
& +D_{m}+(T D)_{l m}+e_{i j k l m n},
\end{aligned}
$$

where $Y_{i j k l m n}=$ observations for dependent variables, $\mu$ = overall mean, $S_{i}=$ fixed effect of diet sequence $i(i=$ 1 to 2$), C(S)_{j(i)}=$ random effect of cow $j$ nested within diet sequence $i\left(j=1\right.$ to 8 ), $P_{k}=$ fixed effect of period $k$ ( $k=1$ to 2$), T_{l}=$ fixed effect of measurement time $l(l$ $=1$ to 4 for days, or 1 to 7 for hours), $D_{m}=$ fixed effect 
Table 2. Data of selected preprandial plasma metabolites and hormones in lactating cows fed 2 different diets

\begin{tabular}{|c|c|c|c|c|c|c|}
\hline \multirow[b]{2}{*}{ Item $^{1}$} & \multicolumn{2}{|c|}{ Diet $^{2}$} & \multirow[b]{2}{*}{ SEM } & \multicolumn{3}{|c|}{ Effect, ${ }^{3} P$-value } \\
\hline & CTR & TRT & & Trt & $\mathrm{D}$ & $\operatorname{Trt} \times \mathrm{D}$ \\
\hline Glucose, $\mathrm{mg} / \mathrm{dL}$ & 60.6 & 66.9 & 0.80 & $<0.01$ & 0.32 & 0.12 \\
\hline Insulin, $\mu \mathrm{g} / \mathrm{L}$ & 0.48 & 0.51 & 0.01 & 0.05 & $<0.01$ & $<0.01$ \\
\hline Cortisol, $\mu \mathrm{g} / \mathrm{dL}$ & 2.85 & 3.13 & 0.41 & 0.53 & $<0.01$ & 0.21 \\
\hline $\mathrm{BHBA}, \mu \mathrm{mol} / \mathrm{L}$ & 366 & 326 & 27.6 & 0.33 & 0.08 & 0.92 \\
\hline Lactate, $\mu \mathrm{mol} / \mathrm{L}$ & 737 & 879 & 76.6 & 0.15 & 0.11 & 0.03 \\
\hline NEFA, mEq/L & 0.26 & 0.23 & 0.04 & 0.46 & 0.01 & 0.25 \\
\hline Cholesterol, mg/dL & 135 & 168 & 8.19 & 0.03 & 0.56 & 0.19 \\
\hline
\end{tabular}

${ }^{1}$ Data across d 12, 15, 17, and 21 of each experimental period $(\mathrm{n}=8)$.

${ }^{2} \mathrm{CTR}=$ control diet containing rolled barley grain steeped for $48 \mathrm{~h}$ in equal quantity of tap water; TRT = treatment diet based on rolled barley grain steeped for $48 \mathrm{~h}$ in equal quantity (wt/vol) of tap water containing $0.5 \%$ lactic acid.

${ }^{3}$ Effect of dietary treatment (Trt), measurement day (D), and treatment by day interaction (Trt $\times$ D).

of diet $l(l=1$ to 2$), T D_{l m}=$ fixed effect of diet by time interaction, and $e_{i j k l m n}=$ random residual effect.

Measurements collected at different times on the same cow were considered as repeated measures in the ANOVA, whereby the effects of day and hour were evaluated separately in the model. The $S_{i}$ and $C(S)_{j(i)}$ terms were included in the model to determine any potential carryover effect. The variance-covariance structure of the repeated measures was modeled separately for each response variable according to the lowest values of the fit statistics based on the Bayesian information criteria and an appropriate structure was fitted. Degrees of freedom were approximated by the method of Kenward-Roger (ddfm $=\mathrm{kr}$ ), and differences at each time point between treatments were conducted with SLICE option of SAS. Least squares means and the respective SEM were computed. Significance was declared at $P \leq 0.05$, and a tendency was considered at $0.05<P \leq 0.10$.

\section{RESULTS}

\section{Plasma Metabolites}

Data showed that cows fed the TRT diet had greater preprandial concentrations of plasma glucose $(P<$ 0.01; Table 2) compared with CTR cows. Measurement day alone or day $\times$ treatment interaction did not affect plasma glucose (Table 2). Results of diurnal variation of glucose in plasma are shown in Figure 1a; diet did not affect the latter variable. Glucose concentration in plasma decreased in both groups after the morning feeding, and this was reflected by an effect of sampling hour after the morning feeding $(P<0.01$; Figure 1a). Interestingly, the ANOVA revealed a treatment $\times$ hour interaction on plasma glucose. Thus, the cows fed the CTR diet demonstrated a lower concentration of glucose (42 vs. $54 \mathrm{mg} / \mathrm{dL} ; P=0.01)$ particularly at $4 \mathrm{~h}$ postfeeding but a greater concentration at $10 \mathrm{~h}$ postfeeding (56 vs. $47 \mathrm{mg} / \mathrm{dL} ; P=0.02$; Figure 1a).

Results also indicated that dietary treatment affected the overall plasma insulin. Cows fed the TRT diet had greater overall preprandial plasma insulin compared with the group of cows fed the CTR diet (Table 2). The ANOVA revealed a daily variation $(P<0.01)$ and a day $\times$ treatment interaction for plasma insulin $(P$ $<0.01$; Figure 2a). Compared with cows on the TRT diet, cows fed the CTR diet showed lower preprandial plasma insulin on d $12(P<0.01)$ and d $15(P<0.01)$ but greater on $\mathrm{d} 17(P=0.03)$ and $21(P<0.01$; Figure $2 \mathrm{a}$ ). On the other hand, diurnal data demonstrated that concentration of plasma insulin was not affected by the dietary treatment (Figure 1b). In both groups, insulin concentration increased after the morning feeding, reaching peak values at $6 \mathrm{~h}$ postfeeding, and this was reflected by a significant effect of the sampling hour after the morning feeding (Figure 1b).

Concentrations of cortisol in the plasma, measured at different experimental days (Table 2) or at different times after the morning feeding (Figure 1c), were unaffected by treatment $(P>0.05)$. However, the factor sampling time expressed either as experimental day or as hour after the morning feeding affected plasma cortisol in the present study $(P<0.01)$. Thus, diurnal plasma cortisol was greatest at $6 \mathrm{~h}$ after the morning feeding $(5.3 \mu \mathrm{g} / \mathrm{dL})$ and on $\mathrm{d} 17(4.2 \mu \mathrm{g} / \mathrm{dL})$ of the experiment. Other results of this study showed that feeding cows the TRT diet did not affect preprandial plasma BHBA (Table 2) or its diurnal concentrations (Figure 3a). The peak concentration of plasma BHBA was reached at 6 to $8 \mathrm{~h}$ postfeeding; only the factor measurement hour affected the concentration of BHBA in the plasma (Figure 3a).

Although diet and measurement day did not affect preprandial plasma lactate in this study, the ANOVA 


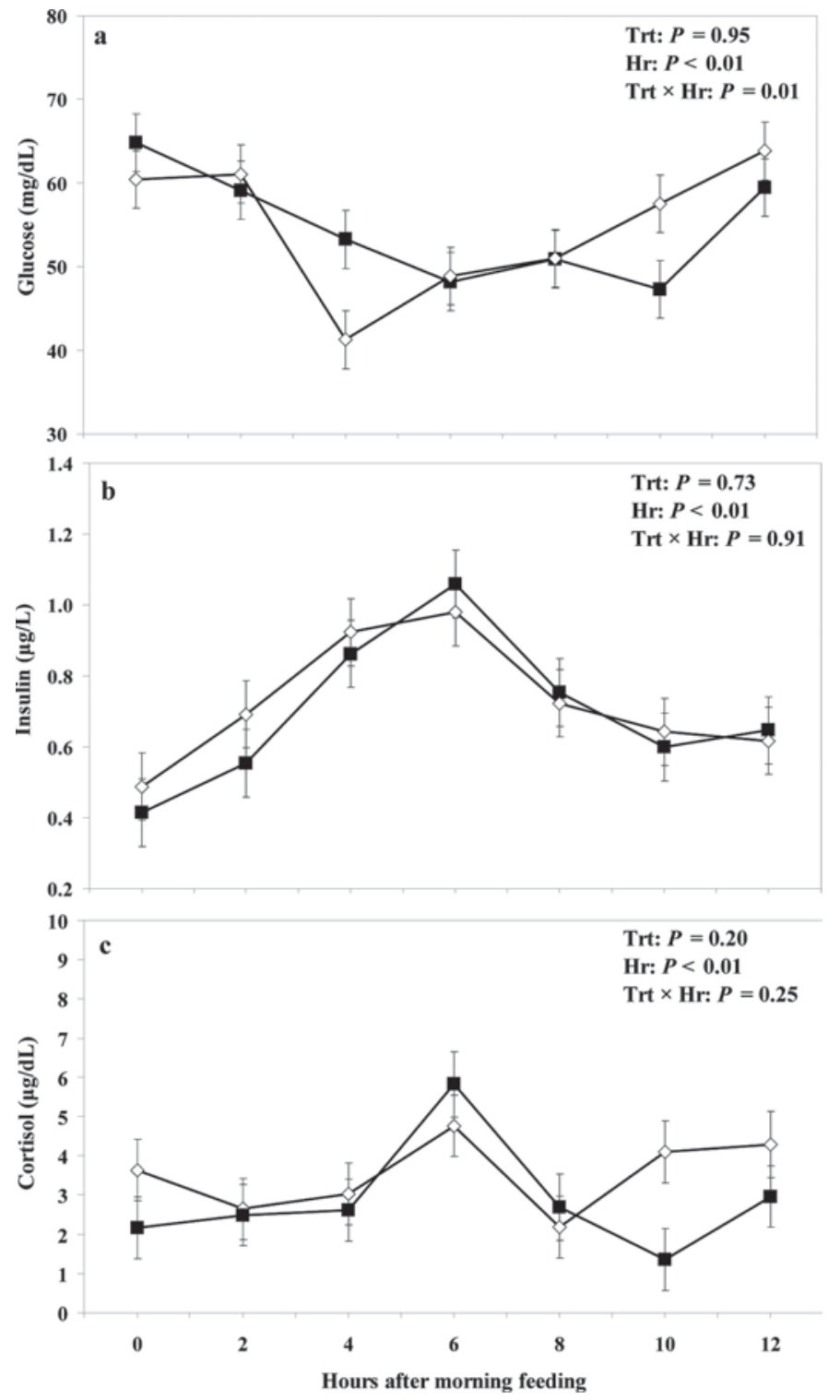

Figure 1. Diurnal variation of glucose (a), insulin (b), and cortiso (c) in plasma of lactating Holstein cows fed rolled barley grain steeped in equal volume $(\mathrm{wt} / \mathrm{vol})$ of tap water $(\mathrm{CTR} ; \diamond)$ or in $0.5 \%$ lactic acid $(\mathrm{TRT} ; \mathbf{\square})$ solution $(\mathrm{LSM} \pm \mathrm{SEM} ; \mathrm{n}=8$; Trt $=$ effect of treatment; $\mathrm{Hr}$ $=$ effect of sampling hour; Trt $\times \mathrm{Hr}=$ effect of treatment by sampling hour interaction).

revealed a diet $\times$ day interaction $(P=0.03$; Figure $2 \mathrm{~b})$. Diurnal plasma lactate showed a tendency to increase in cows fed the TRT diet $(P=0.10$; Figure $3 \mathrm{~b})$. The measurement hour affected diurnal plasma lactate $(P$ $<0.01)$, whereas no treatment $\times$ hour interaction was observed on the latter variable (Figure $3 \mathrm{~b}$ ).

Feeding LA-treated barley grain had no effect on preprandial plasma NEFA at different experimental days (Table 2). In addition, no interaction existed between treatment and day of feeding on plasma NEFA in the present study. However, the factor day of feeding alone showed an effect on concentration of NEFA $(P=0.01$; Table 2). Dietary treatment influenced plasma cholesterol $(P=0.03)$, with cows fed the TRT diet having greater overall preprandial plasma cholesterol on different days (Table 2). In addition, measurement day alone or in combination with dietary treatment had no effect on the latter variable.

\section{Rumen ET and Plasma Acute Phase Proteins}

Concentration of preprandial ET in the rumen fluid was not affected by dietary treatment (Table 3 ). Moreover, both the measurement day and treatment $x$ day interaction had no effect on concentration of ET in the rumen fluid. Data showed that cows fed the TRT diet had lower preprandial concentrations of $\mathrm{Hp}$ in the plasma $(P<0.01$; Table 3$)$. The factor measurement day also affected plasma $\mathrm{Hp}(P<0.01)$, although no effect was observed for the interaction between treatment and day of feeding (Table 2). Diurnal variations of $\mathrm{Hp}$ in the plasma of cows are presented in Figure 4a. Cows fed the TRT diet showed lower diurnal concentrations of Hp compared with the cows fed the CTR diet $(P<$ 0.01; Figure 4a). In addition, plasma $\mathrm{Hp}$ was affected by measurement hour $(P<0.01)$, being lowest at 0 $\mathrm{h}(1.4 \mathrm{mg} / \mathrm{mL})$ and greatest at $12 \mathrm{~h}$ postfeeding $(1.9$ $\mathrm{mg} / \mathrm{mL}$ ). No effect of treatment $\times$ hour interaction on plasma Hp was observed.

Feeding the TRT diet had no effect on preprandial concentration of plasma SAA (Table 3). Furthermore, the factor feeding day alone or in combination with dietary treatment did not affect plasma SAA. On the other hand, diurnal concentrations of plasma SAA tended to be lower in cows fed the TRT diet $(P=0.06$; Figure $4 \mathrm{~b}$ ), and the difference became more pronounced after 10 and $12 \mathrm{~h}$ postfeeding $(P<0.01)$. The measurement hour relative to the morning feeding affected plasma SAA $(P<0.01 ;$ Figure $4 \mathrm{~b})$. The concentration of SAA in the plasma increased from $2.5 \mu \mathrm{g} / \mathrm{mL}$ at $0 \mathrm{~h}$ to 4.2 $\mu \mathrm{g} / \mathrm{mL}$ at $2 \mathrm{~h}$ postfeeding.

Results indicated that the concentration of preprandial LBP in the plasma did not differ between the 2 treatment groups $(P>0.05$; Table 3$)$. However, ANOVA revealed the presence of an interaction between treatment and feeding day (Figure 2c), whereby cows fed the TRT diet had lower concentration of LBP on d 12 (5.7 vs. $3.8 \mu \mathrm{g} / \mathrm{mL} ; P=0.02)$, but greater concentration on d 21 (2.0 vs. $3.8 \mu \mathrm{g} / \mathrm{mL} ; P=0.03)$. The study also showed that the factor day of feeding had an effect on plasma concentration of LBP $(P<0.01$; Figure 2 c).

\section{DISCUSSION}

Results of this investigation supported our 2 working hypotheses that treatment of barley grain with LA 
modulated both energy status and innate immunity of dairy cows. Indeed, our data showed that plasma glucose, insulin, and cholesterol were greater in cows fed the TRT diet. Moreover, measurement of selected innate immunity variables indicated that cows fed the TRT diet had lower plasma SAA and Hp, suggesting that the diet prevented development of an inflammatory state in those cows.

Greater concentrations of glucose, insulin, and cholesterol in the plasma and a tendency for higher plasma lactate in cows fed the TRT diet are in agreement with events occurring in the rumen (Iqbal et al., 2009). As reported in our published companion article, feeding dairy cows barley grain steeped in $0.5 \%$ LA lowered the proportion of soluble starch by $8 \%$ and increased that of resistant starch by $17.7 \%$, thereby lowering the concentration of total VFA in the rumen fluid (Iqbal et al., 2009). Resistant starch is starch that bypasses the upper part of the gastrointestinal tract (i.e., the rumen) and is digested in the intestines (Reynolds, 2006). The results of this study suggest a modulatory effect of LA on the degradation characteristics of starch, associated with subsequent changes in the extent and site of starch digestion as well as with net absorption of glucogenic compounds particularly glucose and propionate (Reynolds, 2006).

As indicated by Sutton et al. (2003), part of the resistant starch is slowly degraded in the rumen to produce mainly propionate; however, most of the resistant starch escapes rumen degradation and is digested in the small and large intestine to provide glucose and VFA to the host (Huntington, 1997; Reynolds, 2006). In fact, in cows fed the LA-treated diet, a tendency for a greater proportion of rumen propionate that might contribute to plasma glucose was reported previously by us (Iqbal et al., 2009). However, greater glucose concentration in the plasma of cows fed the TRT diet might also be attributed to increased starch digestion in the small intestine, provided that treatment lowered in situ degradation of starch and concentration of total VFA in the rumen (Iqbal et al., 2009) and increased preprandial plasma glucose and insulin. The increase in net absorption of glucose from the gut is known to increase glucose supply to the host at the expense of hepatic gluconeogenesis (Huntington, 1997), whereby the latter process is downregulated by an increased concentration of insulin, which is reported to inhibit gluconeogenesis (Rigout et al., 2003). Indeed, in the present study, the preprandial plasma concentration of insulin was increased in cows fed the TRT diet, which indicates an increase in glucose absorption.

Our results were in disagreement with reports from monogastric animals, including human studies, indicating that feeding wholegrain bread treated with LA low-
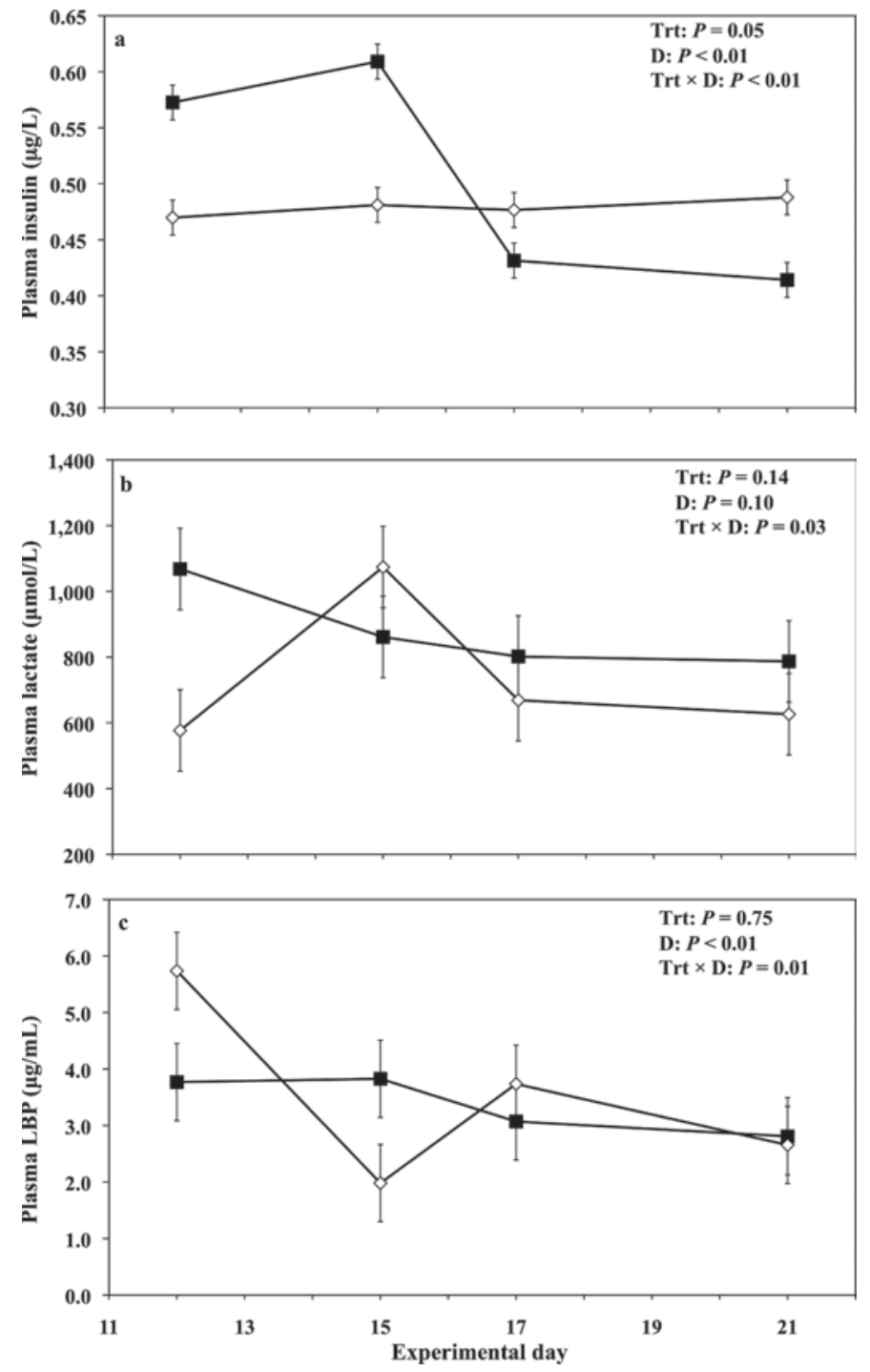

Figure 2. Day-to-day variation of preprandial plasma insulin (a), lactate (b), and lipopolysaccharide-binding protein (LBP; c) in lactating Holstein cows fed diets based on rolled barley grain steeped in equal volume $(\mathrm{wt} / \mathrm{vol})$ of tap water $(\mathrm{CTR} ; \diamond)$ or in $0.5 \%$ lactic acid (TRT; $)$ solution $(\mathrm{LSM} \pm \mathrm{SEM} ; \mathrm{n}=8$; Trt = effect of treatment; $\mathrm{D}$ $=$ effect of sampling day; Trt $\times \mathrm{D}=$ effect of treatment by sampling day interaction).

ers plasma glucose, insulin, and cholesterol (Liljeberg et al., 1995). This discrepancy was anticipated given the differences in the gastrointestinal digestion of resistant starch between ruminants and monogastrics, in which the former digest bypass starch into glucose in the small intestine and less into VFA in the hindgut (Nocek and Tamminga, 1991), whereas the latter digest resistant starch into VFA mainly in the large intestine (Bird and Topping, 2000).

Interestingly, the greater concentration of glucose and insulin in the plasma of cows fed the LA-treated barley grain diet was associated with greater plasma choles- 
Table 3. Data of preprandial rumen endotoxin and different plasma acute phase proteins in lactating cows fed 2 different diets

\begin{tabular}{|c|c|c|c|c|c|c|}
\hline \multirow[b]{2}{*}{ Item $^{1}$} & \multicolumn{2}{|c|}{ Diet $^{2}$} & \multirow[b]{2}{*}{ SEM } & \multicolumn{3}{|c|}{ Effect, ${ }^{3} P$-value } \\
\hline & CTR & TRT & & Trt & $\mathrm{D}$ & Trt $\times D$ \\
\hline Rumen endotoxin, $\mu \mathrm{g} / \mathrm{mL}$ & 0.37 & 0.28 & 0.12 & 0.59 & 0.83 & 0.20 \\
\hline Haptoglobin, $\mathrm{mg} / \mathrm{mL}$ & 1.72 & 1.29 & 0.09 & $<0.01$ & $<0.01$ & 0.09 \\
\hline Serum amyloid A, $\mu \mathrm{g} / \mathrm{mL}$ & 2.86 & 3.15 & 0.28 & 0.39 & 0.06 & 0.12 \\
\hline $\mathrm{LBP}, \mu \mathrm{g} / \mathrm{mL}$ & 3.53 & 3.37 & 0.49 & 0.76 & $<0.01$ & 0.01 \\
\hline \multicolumn{7}{|c|}{$\begin{array}{l}{ }^{1} \text { Data across d } 12,15,17 \text {, and } 21 \text { of each experimental period }(\mathrm{n}=8) ; \mathrm{LBP}=\text { lipopolysaccharide-binding } \\
\text { protein. }\end{array}$} \\
\hline \multicolumn{7}{|c|}{$\begin{array}{l}{ }^{2} \mathrm{CTR}=\text { control diet containing rolled barley grain steeped for } 48 \mathrm{~h} \text { in equal quantity of tap water; TRT } \\
\text { treatment diet based on rolled barley grain steeped for } 48 \mathrm{~h} \text { in equal quantity (wt/vol) of tap water containin } \\
0.5 \% \text { lactic acid. }\end{array}$} \\
\hline
\end{tabular}

terol. In fact, the exact mechanism(s) by which the LA promoted greater cholesterol concentration deserves further consideration. It is well established that blood cholesterol in ruminants derives either from absorption of dietary cholesterol from small intestines or from endogenous synthesis principally in the epithelial cells of gastrointestinal tract (GIT) and less in the liver hepa-
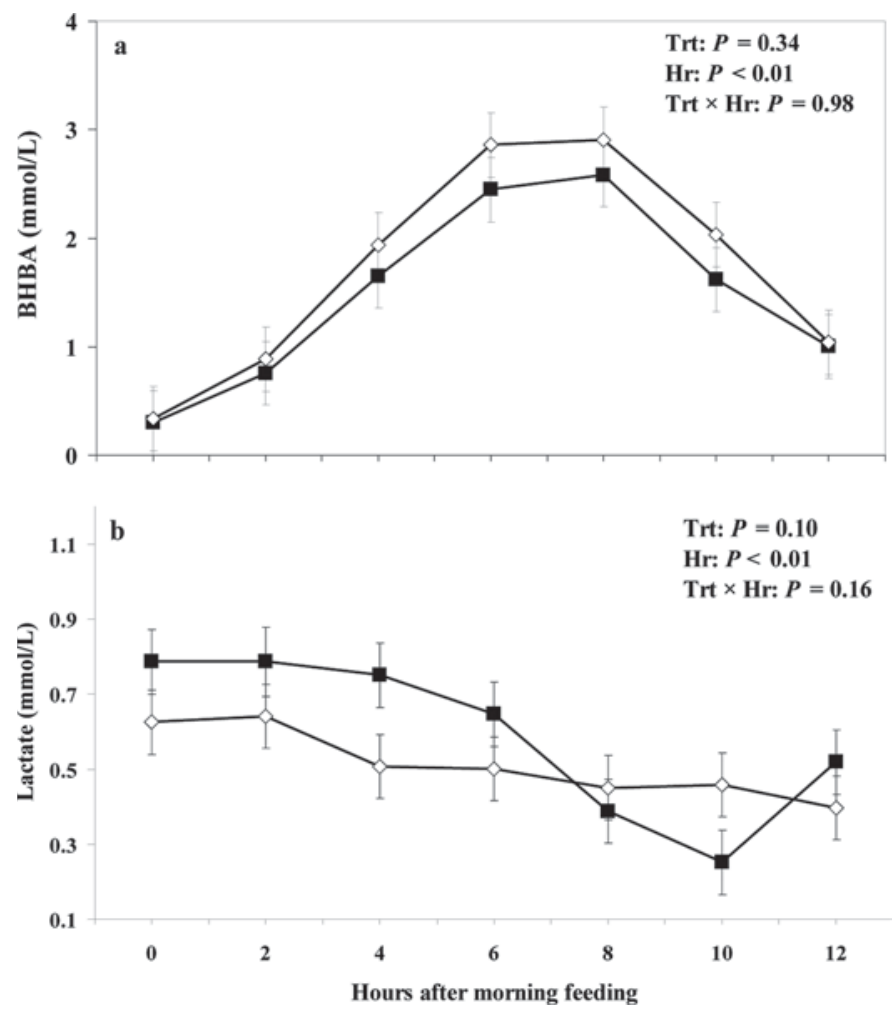

Figure 3. Diurnal variation of BHBA (a) and lactate (b) in plasma of lactating Holstein cows fed rolled barley grain steeped in equal volume (wt/vol) of tap water $(\mathrm{CTR} ; \diamond)$ or in $0.5 \%$ lactic acid (TRT; solution $(\mathrm{LSM} \pm \mathrm{SEM} ; \mathrm{n}=8$; Trt $=$ effect of treatment; $\mathrm{Hr}=$ effect of sampling hour; Trt $\times \mathrm{Hr}=$ effect of treatment by sampling hour interaction). tocytes (Liepa et al., 1978). Because dietary cholesterol was similar between the 2 treatment groups, the greater plasma cholesterol in the TRT cows might be related more to de novo synthesis of cholesterol in the GIT or liver. Acetate is also a precursor to cholesterol in the small intestines (Liepa et al., 1978). The concentration of acetate in the rumen fluid was lower in the treatment group in our previous study (Iqbal et al., 2009), which does not support involvement of acetate from GIT in cholesterol synthesis. The source for greater plasma cholesterol in the TRT group might be the de novo synthesis of cholesterol from glucose in various body tissues such as intestine, adipose tissue, and liver (Liepa et al., 1978). When glucose was used as a precursor of cholesterol, Liepa et al. (1978) reported that 58.4, 28.8, and $2.9 \%$ of total cholesterol in ruminating goats was synthesized in the small intestine, adipose tissue, and liver, respectively. The greater glucose in the plasma of TRT cows might explain the greater plasma cholesterol in cows fed barley grain steeped in LA.

Previously we reported that feeding dairy cows high grain-low forage diets is associated with activation of an acute phase response (APR) and the release of acute phase proteins such as SAA, LBP, and Hp into the blood circulation in dairy cows (Emmanuel et al., 2008). In the present study we observed that feeding comparable proportions of barley grain steeped in LA prevented activation of the APR as reflected by lower concentrations of plasma SAA and Hp. To the best of our knowledge, this is the first report demonstrating a preventive effect of feeding LA-treated barley grain on development of an APR in dairy cows fed diets relatively rich in cereal grains. Both SAA and $\mathrm{Hp}$ in the plasma are considered important acute phase proteins in cattle (Humblet et al., 2006). The known role of SAA is to neutralize and remove ET from blood circulation through hepatocytes (Cabana et al., 1999), whereas $\mathrm{Hp}$ is released during bacterial translocation and its 

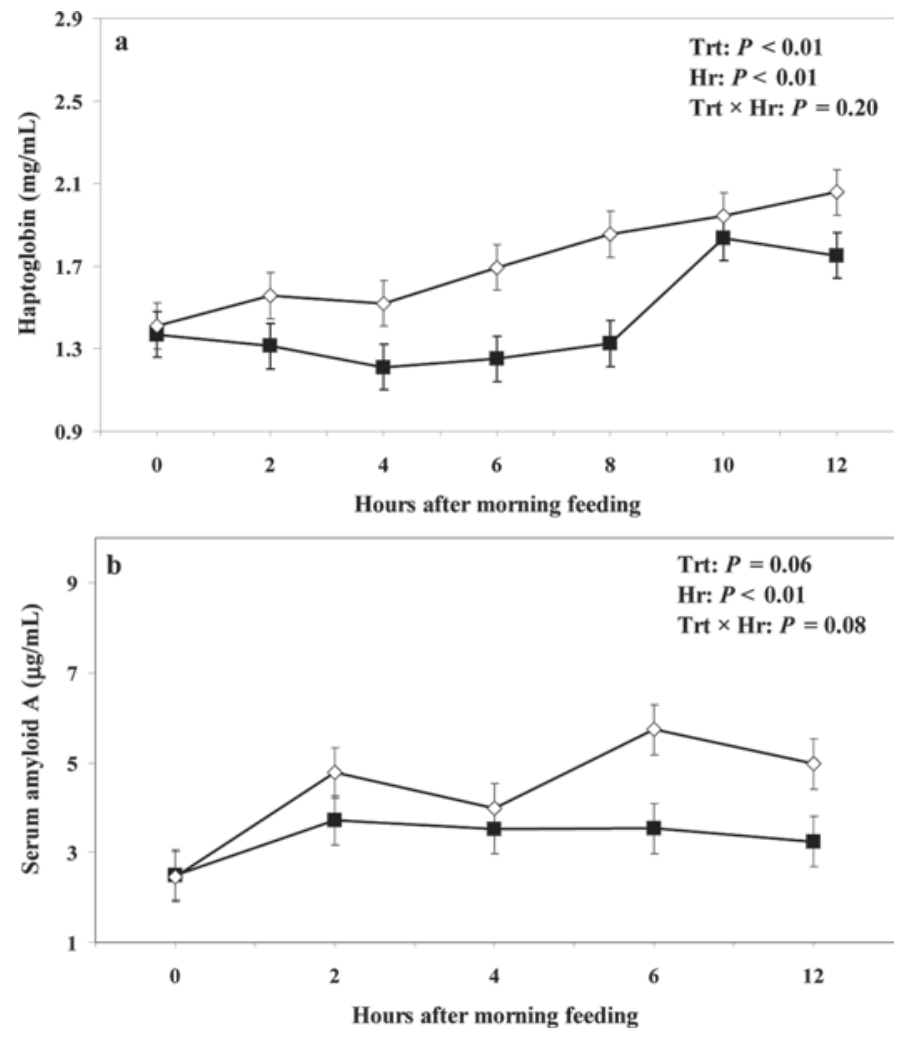

Figure 4. Diurnal variation of plasma haptoglobin (a) and serum amyloid A (b) in lactating Holstein cows fed diets based on rolled barley grain steeped in equal volume (wt/vol) of tap water $(\mathrm{CTR} ; \diamond)$ or in $0.5 \%$ lactic acid (TRT; $\mathbf{\square})$ solution (LSM \pm SEM; $\mathrm{n}=8$; Trt $=$ effect of treatment; $\mathrm{Hr}=$ effect of sampling hour; Trt $\times \mathrm{Hr}=$ effect of treatment by sampling hour interaction).

primary function is to bind plasma free hemoglobin released during hemolysis of red blood cells and prevent utilization of iron contained in the hemoglobin by translocated bacteria (Wassell, 2000).

The mechanistic details explaining the positive effect of TRT diet on innate immunity in this research are not very well understood at present. However, it is speculated that prevention of SARA and improvements in the overall GIT conditions (Iqbal et al., 2009) might have played a role. Interestingly, concentrations of ET in the rumen fluid were not different between the 2 treatment groups. One potential reason why rumen ET was not different between the 2 groups might be that rumen ET was measured before the morning feeding, whereas the differences in plasma $\mathrm{Hp}$ and particularly SAA became more pronounced later after the morning feeding. In support of this postulate are data reported by Khafipour et al. (2009), who indicated that the concentration of ET in the rumen fluid reaches a peak between 6 and $12 \mathrm{~h}$ after the morning feeding in dairy cows fed large amounts of concentrate. The beneficial effects of feeding LA-treated barley grain on better in- nate immunity might be related to improvements in the rumen environment, with greater $\mathrm{pH}$ values in TRT cows versus controls (Iqbal et al., 2009). Recently, we and others showed that low $\mathrm{pH}$ and the presence of ET make rumen and colon tissues highly permeable to nonnutrients (Emmanuel et al., 2007) including bacteria (Go et al., 1995).

We observed only a tendency for plasma lactate to be greater in cows fed the TRT diet, which might be related to conversion of propionate into lactate in the rumen wall (Huntington et al., 1981). In support of this hypothesis are our previously reported data indicating that LA treatment lowered lactate concentration but increased proportions of propionate in the rumen fluid (Iqbal et al., 2009).

Results of the present study showed no differences with regard to plasma BHBA and NEFA between the 2 treatment groups. The reason for that might be that cows in this investigation were in late lactation, where the storage of body tissue protein and fat dominates over those of mobilization processes. It is known that energy absorbed as glucose or VFA from starch digested postruminally is used with high efficiency for body tissue protein and fat storage in late-lactation cows (Reynolds, 2006).

Overall, our results of higher plasma glucose, insulin, and cholesterol and the improved innate immunity in cows fed barley grain steeped in LA might have important implications for early-lactation cows in easing the negative energy balance and related metabolic disorders and in preventing commonly observed inflammatory states at the onset of lactation. Therefore, it would be of interest to further investigate the effects of treating cereal grains with LA in transition dairy cows.

\section{CONCLUSIONS}

Taken together, the results of this study demonstrated that feeding late-lactation dairy cows barley grain steeped in $0.5 \% \mathrm{LA}$ was associated with greater plasma glucose, insulin, and cholesterol, and a tendency for higher plasma lactate. Moreover, data showed lower concentrations of plasma $\mathrm{Hp}$ and SAA in cows fed the LA-treated diet. These findings indicate that steeping barley grain in LA is an advantageous processing technology with regard to both energy status and immunity in dairy cows fed relatively high levels (i.e., $45 \%$ of DM) of dietary concentrate.

\section{ACKNOWLEDGMENT}

We acknowledge the financial support of Alberta Milk (Edmonton, Alberta, Canada), Alberta Livestock Industry Development Fund (Edmonton, Alberta, Can- 
ada), and Natural Sciences and Engineering Research Council of Canada (Ottawa, Ontario, Canada). We are grateful to the technical staff at Dairy Research and Technology Centre, University of Alberta, for their help and care of the cows.

\section{REFERENCES}

Ametaj, B. N., B. J. Bradford, G. Bobe, R. A. Nafikov, Y. Lu, J. W. Young, and D. C. Beitz. 2005. Strong relationships between mediators of the acute phase response and fatty liver in dairy cows. Can. J. Anim. Sci. 85:165-175.

Andersen, P. H. 2003. Bovine endotoxicosis: Some aspects of relevance to production diseases. Acta Vet. Scand. Suppl. 98:141-155.

AOAC. 2002. Official Methods of Analysis. Revision 1. Vol. 1. 17th ed. Association of Official Analytical Chemists, Arlington, VA.

Bird, A. R. I. L. B., and D. L. Topping. 2000. Starches, resistant starches, the gut microflora and the human health. Curr. Issues Intest. Microbiol. 1:25-37.

Cabana, V. G., C. A. Reardon, B. Wei, J. R. Lukens, and G. S. Getz. 1999. SAA-only HDL formed during the acute phase response in apoA-1+/+ and apoA-I-/- mice. J. Lipid Res. 40:1090-1103.

Campling, R. C. 1991. Processing cereal grains for cattle: A review. Livest. Prod. Sci. 28:223-234.

Canadian Council on Animal Care. 1993. Guide to the Care and Use of Experimental Animals. Vol. 1. 2nd ed. CCAC, Ottawa, Ontario, Canada.

Emmanuel, D. G. V., S. M. Dunn, and B. N. Ametaj. 2008. Feeding high proportions of barley grain stimulates an inflammatory response in dairy cows. J. Dairy Sci. 91:606-614.

Emmanuel, D. G. V., K. L. Madsen, T. A. Churchill, S. M. Dunn, and B. N. Ametaj. 2007. Acidosis and lipopolysaccharide from Escherichia coli 055:B5 cause hyperpermeability of rumen and colon tissues. J. Dairy Sci. 90:5552-5557.

Go, L. L., P. J. Healey, S. C. Watkins, R. L. Simmons, and M. I. Rowe. 1995. The effect of endotoxin on intestinal mucosal permeability to bacteria in vitro. Arch. Surg. 130:53-58.

Humblet, M. F., H. Guyot, B. Boudry, F. Mbayahi, C. Hanzen, F. Rollin, and J. M. Godeau. 2006. Relationship between haptoglobin, serum amyloid A, and clinical status in a survey of dairy herds during a 6-month period. Vet. Clin. Pathol. 35:188-193.

Huntington, G. B. 1997. Starch utilization by ruminants: From basics to the bunk. J. Anim. Sci. 75:852-867.

Huntington, G. B., R. L. Prior, and R. A. Britton. 1981. Glucose and lactate absorption and metabolic interrelationships in steers changed from low to high concentrate diets. J. Nutr. 111:11641172 .

Iqbal, S., Q. Zebeli, A. Mazzolari, G. Bertoni, S. M. Dunn, W. Z. Yang, and B. N. Ametaj. 2009. Feeding barley grain steeped in lac- tic acid modulates rumen fermentation patterns and increases milk fat content in dairy cows. J. Dairy Sci. 92:6023-6032.doi:10.3168/ jds.2009-2380.

Khafipour, E., D. O. Krause, and J. C. Plaizier. 2009. A grainbased subacute ruminal acidosis challenge causes translocation of lipopolysaccharide and triggers inflammation. J. Dairy Sci. 92:1060-1070

Liepa, G. U., D. C. Beitz, and J. R. Linder. 1978. Cholesterol synthesis in ruminating and nonruminating goats. J. Nutr. 108:535-543.

Liljeberg, H. G. M., C. H. Lonner, and I. M. E. Björck. 1995. Sourdough fermentation or addition of organic acids or corresponding salts to bread improves nutritional properties of starch in healthy humans. J. Nutr. 125:1503-1511.

McCleary, B. V., and D. A. Monaghan. 2002. Measurement of resistant starch. J. AOAC Int. 85:665-675.

Nocek, J. E. 1997. Bovine acidosis: Implications on laminitis. J. Dairy Sci. 80:1005-1028

Nocek, J. E., and S. J. Tamminga. 1991. Site of digestion of starch in the gastrointestinal tract of dairy cows and its effect on milk yield and composition. J. Dairy Sci. 74:3598-3629.

NRC. 2001. Nutrient Requirements of Dairy Cattle. 7th rev. ed. Natl. Acad. Sci., Washington, DC.

Reynolds, C. K. 2006. Production and metabolic effects of site of starch digestion in dairy cattle. Anim. Feed Sci. Technol. 130:78-94.

Rhee, K. C. 2005. Determination of total nitrogen. Pages 105-113 in Handbook of Food Analytical Chemistry: Water, Proteins, Enzymes, Lipids, and Carbohydrates. R. E. Wrolstad, E. A. Decker, S. J. Schwartz, and P. Sporns, ed. John Wiley and Sons, Hoboken, N.J.

Rigout, S., C. Hurtaud, S. Lemosquet, A. Bach, and H. Rulquin. 2003 Lactational effect of propionic acid and duodenal glucose in cows. J. Dairy Sci. 86:243-253.

SAS Institute. 2003. SAS User's Guide: Statistics. Release 9.1.3. SAS Inst. Inc., Cary, NC.

Sutton, J. D., M. S. Dhanoa, S. V. Morant, J. France, D. J. Napper, and E. Schuller. 2003. Rates of production of acetate, propionate, and butyrate in the rumen of lactating dairy cows given normal and low-roughage diets. J. Dairy Sci. 86:3620-3633.

Theurer, C. B. 1986. Grain processing effects on starch utilization by ruminants. J. Anim. Sci. 63:1649-1662.

Van Soest, P. J., J. B. Robertson, and B. A. Lewis. 1991. Methods for dietary fiber, neutral detergent fiber and non-starch polysaccharide in relation to animal nutrition. J. Dairy Sci. 74:3583-3597.

Wassell, J. 2000. Haptoglobin: Function and polymorphism. Clin. Lab. 46:547-552.

Zebeli, Q., D. Mansmann, H. Steingass, and B. N. Ametaj. 2010. Balancing diets for physically effective fibre and ruminally degradable starch: A key to lower the risk of sub-acute rumen acidosis and improve productivity of dairy cattle. Livest. Sci. 127:1-10. 